\title{
Legal Justice or Social Justice?
}

\author{
Debating the Rule of Law in Tannaitic Literature
}

\author{
Chaya Halberstam (King's University College)
}

\begin{abstract}
This article aims to read closely the tannaitic material pertaining to judicial discretion and legal justice with the understanding that the rabbis are not simply clarifying certain specialized questions about courtroom procedure but are seriously engaging a core facet of Roman imperial and Hellenistic ideology: the benefits and deficits of the rule of law. It has been noted that as opposed to later, talmudic rabbis, the Tanaaim are particularly strict with regard to personal, judicial discretion - in other words, that rather than strike a balance between law and wisdom, they allow only for rule-based decision making. This article suggests that the Tanaaim not only opt for rule-bound decision making, but that they do so with a full awareness of what is lost from broader ideals of social justice when judges are required to abide, almost mechanically, by the rules. The Tanaaim thereby contributed to contemporary questions in political philosophy from the point of view of disempowered Roman provincials for whom the rule of law meant less as political propaganda and more as a measure of stability in uncertain times.
\end{abstract}

Early rabbinic texts on judges and judging stand at an interesting cultural crossroads. On the one hand, deferring continually to biblical texts in which judging is an act of wisdom and inspiration, ${ }^{1}$ tannaitic texts envision judges similarly endowed with humility and virtue: rather than anxiety about corrupt judges, we find far more concern in tannaitic texts with the way well-meaning judges can be led astray. ${ }^{2}$ On the other hand, tannaitic texts about judging, both in form and content, thoroughly reflect the "rule of law" ideology that was the hallmark of the Roman and Greek worlds, and an integral component of Hellenistic Jewish literature. ${ }^{3}$ Namely, the rabbis imagine judges applying rabbinic law in dispute resolution, as they themselves interpret and apply biblical law to questions of proper judicial procedure. Did the early rabbis thus discard the traditional, Torah ideal, exemplified by King Solomon, that a judge could attend closely to the particular circumstances of each litigant and rule from a place of wisdom, compassion, and inspiration? Did they instead opt for the thoroughly Roman notion that "a populus" must be "united by ... consensual commitment to a particular normative order," as Cicero put it?

In a sense, the answer is yes, but to assume this answer - to approach tannaitic rules of judging as already part of a rational, "normative order" - is

1 See J. Burnside, God, Justice, and Society: Aspects of Law and Legality in the Bible (New York: Oxford University Press, 2010), 103-44.

2 See below.

3 See M. LeFebvre, Collections, Codes, and Torah: The Re-Characterization of Israel's Written Law (New York: T \& T Clark, 2006), chapter 5.

4 As quoted in C. Ando, Imperial Ideology and Provincial Loyalty in the Roman Empire (Berkeley: University of California Press, 2000), 48. 
to beg the question. ${ }^{5}$ I would like to suggest in what follows that tannaitic literature records a debate, when it talks about judging, ${ }^{6}$ about this broader question of the relationship between strict adherence to law and broader aims of justice. It is my contention that in debating the limits of judicial discretion for judges, the rabbis are indeed engaging, at times directly and at times incidentally, this central, political-philosophical question of the value of the rule of law and its limits. ${ }^{7}$ We may thus understand the Tanaaim as constructing an understanding of law as a disembodied system of rules and precedent a normative order - rather than proceeding from a presumption that legal discourse must be so. That the Tanaaim do construct law in this way may be seen as arising from a particular historical context rather than standing as an inevitable or necessary conclusion.

Therefore, this article aims to read closely the tannaitic material pertaining to judicial discretion and legal justice ${ }^{8}$ with the understanding that the rabbis are not simply clarifying certain specialized questions about courtroom

5 Aaron Kirschenbaum, in his book on this topic, makes this assumption from the first page onward: "The law's generality and rigid impartiality make for constancy and order in human society. Adherence to formalism is a characteristic of the law necessary for its internal integrity and proper functioning." See A. Kirschenbaum, Equity in Jewish Law: Halakhic Perspectives in Law: Formalism and Flexibility in Jewish Civil Law (Hobokon, N. J.: Ktav Publishing House, 1991), 3. He goes on to show that ideas akin to Aristotle's “equity" have central roles in rabbinic texts about judicial procedure. Regardless, while his work is an important treatment of these questions, it approaches all of Jewish law as a single, holistic system, and thus his conclusions are not particularly relevant for this study of just the tannaitic era of rabbinic literature.

6 The connection between individual instances of judgment - and the role of the judge - as pivotal in the notion of the rule of law is delineated clearly by Judith Shklar in assessing Aristotle's understanding of the concept: "In Aristotle's account the single most important condition for the Rule of Law is the character one must impute to those who make legal judgments." See J. N. Shklar and S. Hoffmann, Political Thought and Political Thinkers (Chicago: University of Chicago Press, 1998): 23.

7 Ari Bryen, in a recent article entitled "When Law Goes Off the Rails, Or, Aggadah Among the Iurisprudentes," Critical Analysis of Law 3.1 (2016): 9-29, makes a similar methodological claim about the writing of Roman jurists that I think applies equally to the tannaitic rabbis. He writes:

The Romans never developed an analytical vocabulary for talking about law itself, or issues of law's legitimacy: both of these kinds of inquiries were just parts of a broader discussion of ius, and even then, they remained quite undeveloped in the early Empire (c. AD 1-250), a historical period not given to sophisticated political theorizing. What attempts there were often feel like inchoate rumbles, as authors push against generic constraints. (12-13)

Bryen borrows the term "aggadah" from scholarship on the Talmud to refer to these texts, which confuses the issue somewhat when trying to bring this type of thinking back to rabbinics. Nevertheless, I similarly endeavour to locate moments within a broader rabbinic "discussion of ius" which push against dominant modes of rabbinic, legal thought, in obvious and more subtle ways.

8 Throughout this article, I use the phrase "legal justice" to mean a narrow type of justice, rather than "justice" broadly conceived: "legal justice" is what results when people are treated according to what the law dictates. For a fuller explanation see D. J. Luban, "Justice and Law" in International Encyclopedia of the Social \& Behavioral Sciences (eds. N. J. Smelser and P. B. Baltes; Oxford: Pergamon, 2001): 8042-48. 
procedure but are seriously engaging a core facet of Roman imperial and Hellenistic ideology: the benefits and deficits of the rule of law. It has been noted that as opposed to later, talmudic rabbis, the Tanaaim are particularly strict with regard to personal, judicial discretion - in other words, that rather than strike a balance between law and wisdom, they allow only for rule-based decision making. ${ }^{9}$ What I would like to suggest in the pages that follow, then, is not simply that the Tanaaim seem to opt for rule-bound decision making, but that they did so with their eyes open - in other words, with a full awareness of what is lost from broader ideals of social justice ${ }^{10}$ when judges are required to abide, almost mechanically, by the rules. The Tanaaim thereby contributed to contemporary questions in political philosophy from the point of view of disempowered Roman provincials for whom the rule of law meant less as political propaganda and more as a measure of stability in uncertain times.

\section{Awareness of the Limits of Legal Justice: Legal Judgment vs Mediation in the Tosefta}

The primary witness to the tannaitic awareness of the limits of rule of law ideology occurs in the first chapter of Tosefta Sanhedrin in the form of a dispute over whether rule-bound, legal justice ought to be preferred to alternative forms of dispute resolution. Approximately a full half of the first chapter of Tosefta Sanhedrin deals with the question of why and whether legal justice is a virtue. The opinion in favour of strict, rule-bound decision making sees it as aligned with absolute, divine truth - a value which they believe ought not be undermined, even as it can be supplemented by other acts of benevolence. The opinion which prefers mediated compromise to strict legal justice does not seem to value legal reasoning for its own sake, but rather chiefly as it can serve broader interests of social justice. ${ }^{11}$ By homing in on the role of the judge

9 See H. Ben-Menahem, Judicial Deviation in Talmudic Law: Governed by Men, Not by Rules (New York: Harwood Academic Publishers, 1991), 121-22.

10 I use "social justice" here in a broad sense, perhaps along the lines of Peter Brown's "aesthetics" of society, i. e., considerations of "what constituted a good society and what constituted an ugly society" (P. Brown, "Remembering the Poor and the Aesthetic of Society," in Journal of Interdisciplinary History 35.3 [2005]: 513-22, 514). Because the rabbis' considerations primarily revolve around basic inequalities, the term "social justice" seems more appropriate to me here.

11 The broader concerns that I have roughly termed "social justice" are here represented in several ways: the duty to foster harmonious community relations even among disputants, the requirement of providing a livelihood for the poor, and the protection of the vulnerable from the strong and powerful. Even though it is the main subject of this article, the Tanaaim do not actually have a word for "justice," even though the biblical term tsedeq is cited and interpreted in tannaitic midrash. A. Radzyner explains that the Tanaaim actually had two different concepts of justice, depending on the situation: for monetary law, justice $=$ legal truth, and for criminal law, justice = viewing the defendant favourably. See A. Radzyner, “Justice, Justice Shall You Pursue': Varied Concepts of Judicial Justice in Tannaitic Doc- 
in adjudicating disputes, the Tosefta here puts the "rule of law" philosophy to the test: is sustaining an independent, rational system of legal thought a good in its own right, or must it simply be a means to a just end? ${ }^{12}$

The Tosefta first advances the notion that only strict legal justice is godly, while mediated compromise transgresses God's will:

Just as judgment is done before three judges, so also compromise ${ }^{13}$ is with three. Once the verdict is reached one is not allowed to compromise.

R. Eleazar b. R Jose the Galilean, says: whoever compromises, that one transgresses. And whoever praises one who compromises, that one blasphemes before God. About this it is said: "one who blesses a botse'a, insults the Lord" [Ps 10:3]. ${ }^{14}$ Rather, let the law

trine" in My Justice, Your Justice: Justice Across Cultures (ed. Y.Z. Stern; Jerusalem: The Zalman Shazar Center for Jewish History, 2010), 59-110 [Hebrew]. He also argues that they did not align the concept of compromise, or pesharah, with tsedeq and therefore did not see it as a kind of justice (Radzyner, ibid., 105-09). The evidence as Radzyner presents it, however, points to the Tanaaim as essentially aligning the word tsedeq with particular types of procedural justice. Here, I wish to discuss their understanding of "justice" in the broader sense in which it is commonly used as a rubric by which to measure a society. This idea of "justice" varies from culture to culture; it might include distributive justice, equality of opportunity, freedom from arbitrary violence, etc. I use "justice" or "social justice" throughout this article not as a precise term, but as a heuristic one that signals a multifaceted array of social values that the Tanaaim themselves invoke.

12 Haim Shapira frames the dispute in a somewhat different way, seeing it as an argument between two different visions of justice, corrective vs distributive, in his article "The Debate Over Compromise and the Goals of the Judicial Process," Dine Israel 26-27 (2010): 183228, 223-26. I follow Christine Hayes however in seeing the debate as a conflict between (what is understood to be) truth and other ideals which include justice, however rendered. See C. Hayes, What's Divine about Divine Law? Early Perspectives (Princeton: Princeton University Press, 2015), 185-86.

13 I have translated the word pesharah here as compromise instead of the more usual "arbitration" because there is far too much ambiguity surrounding the legal process understood as arbitration for it to be a meaningful word. For example, arbitration can refer to any kind of dispute resolution done outside a formal courtroom without any reference as to method. It seems clear from various rabbinic texts that pesharah here specifically refers to a kind of mediated settlement in which there is no clear winner on either side - either funds are distributed or an otherwise middle-of-the-road solution is found. Hence, the English word "compromise" seems most suitable. See I. Lipschits, "The Meaning of P'shara," Alei Mishpat: The Law Review of the Academic Center of Law \& Business 8 (2010): 395-426 [Hebrew]; especially pp. 423-25. In addition, I am persuaded by Lipschits that the terms pesharah and bitsu' $a$ are used synonymously in the Tosefta and later rabbinic texts, even if they have distinct origins. See ibid., 420-23.

14 The root $b$-ts-' in biblical Hebrew denotes profiting or gaining advantage, and the root $b$ $r-k h$, when used with a divine object, is most often a euphemistic use of "bless" to actually mean "curse." The first part of the verse in Psalms reads: "The wicked boasts of the desires of his heart," and so this half-verse in Psalms most likely means something like "and he who seeks profit curses and insults the Lord." (Or, as per the NRSV, "those greedy for gain curse and renounce the Lord.") The poetic verse has a chiastic structure: (A) The wicked [boasts of his] (B) selfish desires // (B) those seeking profit (A) curse and insult the Lord. The rabbis read the verb $b$-ts-' in Mishnaic Hebrew as someone who compromises or facilitates a compromise, and then they read the verb "bless" plainly instead of euphemistically. Hence they arrive at the reading: whoever blesses someone who compromises insults the Lord. 
[ha-din] pierce the mountain, as Moses said, let the law [ha-din] pierce the mountain. ${ }^{15}$ But Aaron pursued peace between fellow men, as it is said, "he walked with me in peace and uprightness," [Mal 2:6] etc. ${ }^{16}$

Rabbi Eliezer b. Jacob says: why does scripture say, "one who blesses a botse'a, insults the Lord"? They related a parable: To what may the matter be compared? To one who stole a se'ah of wheat, ground it, baked it, separated the dough-offering from it, and fed it to his children. How can he recite a blessing? He does not bless, but blasphemes. And about this it is said: "a botse'a who blesses, insults the Lord." ${ }^{17}$ (t. Sanh. 1:2; Zuckermandel p. 415) ${ }^{18}$

The opinion that upholds strict legal judgment as the only valid form of dispute resolution is shared by R. Eleazar b. R. Jose the Galilean and R. Eliezer b. Jacob. For them, God is equated with substantive truth, and to veer from that is to reject God implicitly. For R. Eleazar, law has the power to pierce through any resistance, and it must be used to do so, regardless of the consequences. To effect a compromise which, by definition, means that each party has agreed to the outcome, is equated with theft by R. Eliezer. Finally, according to R. Eleazar, anyone who even praises those engaged in compromise is likened to one guilty of what in the biblical and rabbinic world view was viewed as a capital crime, blasphemy.

The rhetoric in this Tosefta advocates for a strictly formal approach to adjudication: any deviation from the ostensibly determinate requirements of the application of the law, even to the parties' satisfaction, is a perversion of justice, rather than a fulfillment of it. The first supporting text about Moses upholding the law includes a passage that suggests that law is not enough to sustain a community, by informing us that Moses' brother and priestly counterpart Aaron assiduously pursues peace while Moses pursues the law. ${ }^{19}$ If that is the case, the passage concedes that if legal truth is aggressively pursued, it may need to be complemented by other social practices that can restore harmony to the community.

15 There is no verse citation here, which is unusual, especially as these words are placed into the mouth of Moses. Commentators have linked this idea with Moses adjudication in the wilderness (see Exod 18:16), or Moses' exhortation that judges not be afraid of making difficult decisions (Deut 1:17). See I. Lifshitz, Compromise in Jewish Law (Ph. D. diss., Bar Ilan University, 2004), $76 \mathrm{n} .48$ [Hebrew] for a fuller explanation of the phrase and its connection to Moses.

16 Conveniently, this midrash leaves off the first part of the verse in Malachi, which reads: 'True instruction was in his mouth, and no wrong was found on his lips." This sounds a lot more like the pursuit of truth rather than compromise and peace.

17 The verse is read differently, here. The rabbis shift the subject and object around in order to produce the reading they desire. In the previous interpretation, the botse' $a$ is the object; the subject is the implied third person pronoun of the verb "[one] blesses." Here, the parable implies that it is the botse' $a$ who recites the blessing, placing it as the subject of the verb: "the botse'a who blesses insults the Lord."

18 Translations are my own.

19 Perhaps the redactor brings this text in order to suggest that "peace" is somebody else's problem: leave that to others, not the judges or the jurists. According to Rashi (b. Sanh. 6a), Aaron's activity firmly takes place outside the court, before the trial. 
The second supporting text is a parable that works best if one has a formalist notion of theft as an absolute evil; if one approaches the parable from a social justice perspective in which theft might be a response of the desperate and needy to gross social inequalities, the parable unravels. Thus, the narrative constructed to serve the ends of strict legalism ${ }^{20}$ opens itself up to alternative readings: read against the grain, it raises the question of why a man so careful to separate the dough offering and recite a blessing, who uses the one loaf he bakes not for personal gain but to feed his children, would steal a se'ah of grain to begin with? Was the man hungry, poor, and desperate? Did he mistake owned grain for ownerless sheaves? Is he an angry tenant-farmer being underpaid by his overlords and thus stole grain in revenge? The decisive, concluding "moral" of this parable deems none of these particular elements of the story relevant, and asks us to see the theft as an absolute wrong. But the narrative of the parable plausibly undercuts the necessity of this decisive verdict: it is not clear at all, to the reader, that the man in the parable blasphemes the creator. Only a very narrow rendering of justice would see no room for anything but condemnation.

A more expansive idea of justice appears to motivate the next comment in the Tosefta, which opposes the preeminence of strict, legal justice:

Another Interpretation: “one who blesses a botse'a, insults the Lord." These are the brothers of Joseph, who said: "what profit do we gain if we kill our brother?" [Gen 37:26].

R. Joshua b Qorha said: it is a commandment to compromise. As it is said: "truth, and judgments of peace [mishpat shalom], shall you judge in your gates"21 (Zech 8:16). And is it not the case that in every place where there is true judgment [mishpat 'emet] there is no peace? And in every place that there is peace there is no true judgment [mishpat 'emet]? Where do we find [true ${ }^{22}$ judgment [mishpat 'emet] wherein one finds peace? One must say: this is compromise. ${ }^{23}$

And thus it says with regard to David "and David administered justice [mishpat u'tsedaqa] among all his people" (2 Sam 8:16). And is it not the case that in every place where there is legal justice [mishpat] there is no [tsedaqa] charity? And every place that there is charity [tsedaqa] there is no legal justice [mishpat]? One must say: this is compromise. (t. Sanh. 1:3; Zuckermandel p. 415)

20 Contra Shapira, “The Debate Over Compromise," 211, I see this passage as having a conceptual - and not just associative - link with the debate about compromise vs legal justice.

21 I have attempted to render this half-verse as literally as possible. The NRSV translates: "render in your gates judgments that are true and make for peace"; JPS has: "render true and perfect justice in your gates." There is quite a bit of leeway in understanding these terms, which I will discuss below.

22 Some Mss have this word and some do not. See Radzyner, "Justice, Justice Shall You Pursue,"' $98 \mathrm{n}$. 137. The presence or absence of the word 'emet here does not really affect the discussion here, as in any case the word mishpat here would connote a limited idea of legal justice.

23 A parallel text appears in in Sifre Deuteronomy pisqa 17, with both opinions on compromise also represented. 
This tosefta preserves the dichotomy between mishpat (here perhaps best rendered as "legal justice") and peace or charity, seeing them as essentially separate social or institutional spheres. Nevertheless, it sees in the act of mediated compromise a true combination of both values rather than an upholding of one at the expense of the other.

The first pericope simply renders inert the verse that was used in the previous tosefta to impute a negative valence to the compromiser by severing the link between the term botse'a in Psalms 10 and the mishnaic Hebrew bitsu'a meaning compromise. They link the verb to its use in Genesis 37, in the context of Joseph's brothers, in which the root $b$-ts-'refers to ill-gotten gain; they remark that the botse' $a$ of the verse in Psalms that creates the parallel to the blasphemer refers not to a general category of people who negotiate compromises but specifically to Joseph's brothers; those who praise Joseph's brothers insult the Lord by extolling those who profited off the sale of their own flesh and blood. ${ }^{24}$ There is an element of "compromise" in this case, in which those brothers' who wanted to kill Joseph settle for merely selling him to the Ishmaelites, as Judah proposes. But the point is that in this case, the compromise is not just, but an attempt to profit off injury to an innocent party. And in this specific case (or perhaps this class of cases), bets'a does in fact insult the Lord.

But the tosefta continues: not only is compromise not blasphemous, it is actually a divine commandment. The way the tosefta derives this commandment is by constructing compromise as a kind of juridical practice that unites the values of legal justice with peace or charity - two other important ideals in a larger vision of social justice. Strict adherence legal justice neglects the full gamut of social needs, the tosefta argues, and dispute resolution via mediated compromise allows the judge(s) to hear the concerns of the claimants and address them not only via strict legal reasoning but also by encouraging generosity and a spirit of good will. In this type of dispute resolution, it is important not only to reach a conclusion, but to end the court proceedings with both litigants feeling relatively satisfied. ${ }^{25}$

The tosefta makes this point in two very similar pericopes, each of which makes the claim that a society ("place") that only values one side of the legal justice / peace-and-generosity divide will not actually be a place that fulfills the ideals of social justice. As we shall see below, tannaitic literature for the most part upholds the notion of the rule of law as a means of reining in arbitrary violence and fulfilling the words of the Torah, but in this tosefta we see an acknowledgment that the rule of law in a strict sense leads to social discord

24 There is, perhaps, a slightly subtler argument here in that the motive of profiting of the sale of Joseph in fact prevents a greater harm, which is his murder. Nevertheless, the midrashic reading of this verse here insists that praising this action is insulting to God.

25 Contemporary legal practice that prioritizes similar values is usually referred to as "restorative justice." See E. Segal, "Jewish Perspectives on Restorative Justice," in The Spiritual Roots of Restorative Justice (ed. M. Hadley; Albany, N. Y.: State University of New York Press, 2001) 193-94. 
and a pervasive attitude of parsimony both of which are here rejected as communal ideals.

The only difference between the two passages is the biblical verse cited and the resulting noun serving as the counterweight to legal judgment. The first, "shalom," peace, merely addresses the discord that results from an antagonistic trial and a verdict that declares one litigant the winner and one the loser. The authors of this midrash seem to know all too well that this kind of legal process, far from bringing an end to strife, all too often allows it to intensify. In the second passage, the term shifts from "shalom" to "tsedaqa," a word which rather consistently in rabbinic dialect means charity or almsgiving, even though it has a much more expansive meaning in its earlier history. ${ }^{26}$ In this case, the word "tsedaqa" must be taken more expansively not just as a material gift to the poor but as a charitable or generous act in general. This seems clear both from the context in this passage, in which we have no mention of wealth disparity or impoverishment, as well as from the context of Tosefta Sanhedrin 1:5 (cited below) in which the act of "tsedaqa" is understood as a "charitable" removal of property from the one who is holding it. Compromise or mediation, in place of strict legal judgment, is thus seen not only as a means to prevent ongoing feuding, but also as a means of ensuring that members of the community act generously and charitably toward one another rather than insisting on the full measure of their rightful entitlements. ${ }^{27}$ This tosefta thus explicitly posits a "golden mean" between strict "rule of law" practice on the one hand, and an ethic of care unchecked by legal justice on the other - one that fosters a caring community and promotes a rich, comprehensive idea of social justice.

In the next two passages in the Tosefta, the defenders of legal justice take up the theme of tsedaqa, demonstrating how that value may be upheld even without recourse to compromise. Two different perspectives are presented. Neither rejects tsedaqa, as both see generosity as a central value, but each sees its relationship to legal justice differently:

If one rendered a verdict, clearing the one in the right and declaring liable the one who is liable - if one declared a poor personal liable, he takes out his own funds and gives them to him. We find that he does an act of charity [tsedaqa] with this one, and he judges [dan] this one. (t. Sanh. 1:4; Zuckermandel p. 415)

Rabbi says: If one rendered a verdict, clearing the one in the right and declaring liable the one who is liable - we find that he does an act of charity with the one who is liable, since he removes stolen property from his possession, and legal judgment with the one in the right as he returns to him that which is his. (t. Sanh. 1:5; Zuckermandel p. 415)

26 See F. Rosenthal, "Sedaqa, Charity," HUCA 23 (1950-51): 411-30, for the development of the term.

27 Other versions of this midrash, seen in the later, Amoraic compilation Genesis Rabbah as well as the Babylonian Talmud, do take the word tsedaqa here as almsgiving, and conflate this interpretation with the next one in the Tosefta. See Radzyner, "Justice, Justice Shall You Pursue,"” 98 n. 138. 
While the first opinion does not overtly reject compromise, it proffers from the outset a scenario of a completed legal judgment, a verdict rendered. Even then, the anonymous opinion states, the ideal of "mishpat u'tsedaqa" (in the rabbinic reading: "legal justice and generosity") can be maintained: if the judge declares a poor personal legally liable in a case that requires him to pay the other claimant, he may (must?) make up for that loss by giving alms to him from his own, personal funds. As a mode of practice, this rule seems untenable: if judges had to remunerate all financially disadvantaged claimants they ruled against, the burden of social inequity would be lopsidedly placed on judges. Moreover, if poor people knew they would receive funds in each and every case simply by walking into a courtroom, there would be no disincentive to avoid instigating frivolous lawsuits (or, in fact, committing fraud or theft in the first place). Instead of a pragmatic policy, the tosefta must instead be read as taking a stand on a theoretical issue: the conflict between strict legal justice and generosity. The tosefta splits the persona of the judge into two: the judge's "professional" obligation as an adjudicator bound by the rule of law, and his personal/social obligation to give charity to the poor. It assumes that charity is an important obligation falling upon each member of the community, but still insists that it ought not influence the judge's "professional" assessment of the claimants' legal rights and entitlements. At the same time, just because tsedaqa is here siphoned off from the judge's professional responsibility does not necessarily render it as optional: the obligation to give to the poor person standing before him may be just as legally binding as the property rights at issue in the dispute. ${ }^{28}$ Theoretically the splitting of responsibilities into professional and personal - or legal and social - might be an attractive way to solve the dilemma of achieving both legal and social justice ideals, but because of this system's high degree of impracticality the dilemma largely remains unsolved. ${ }^{29}$

In this passage, we are presented with an act of generosity and an act of legal justice as two distinct acts, both performed in relation to the same person: the impoverished claimant receives both a legal judgment and a charitable gift, both of which are rightfully directed at him or her, but both of which derive from two distinct spheres of social practice. In the second passage, Tosefta Sanhedrin 1:5, legal justice and generosity are understood as combined in a single act, much as an earlier passage suggested about compromise; unlike the

28 On the obligation to give to the poor in tannaitic literature, see G. Gardner, The Origins of Organized Charity in Rabbinic Judaism, (New York: Cambridge University Press, 2015): 128-37.

29 The tosefta may be intimating not that every judge needs to literally financially rescue every poor claimant whom he rules against, but rather that other social institutions to which the the judge is obliged to donate - the tamhuy and the quppa (see Gardner, Organized Charity, 84-138) - constitute separate social institutions which fulfil "tsedaqa" while the institution of the court fulfils "mishpat." This would be a fair reading of the tosefta, though it departs from the plain sense reading of its words, which indicate an act of almsgiving happening in the moment after the verdict. 
compromise pericopes, however, the two values are not fused in an expanded concept of justice, but still kept wholly distinct. According to this passage, an act of generosity is redefined, counter-intuitively understood to pertain to being declared liable and giving up money or property. The judge's "generosity" is his "generously" saving the litigant from transgressing the law (and God's will?) by benefiting from stolen property. The winner of the case, according to this tosefta, receives legal justice rather than generosity, because he or she is simply repaid what is rightfully his or hers.

In what sense can being declared liable be seen as an act of charity? ${ }^{30}$ Here we see the absolute adherence to the strict application of statute and precedent - the most maximal rendering of the "rule of law" - thoroughly aligned with real, substantive truth and raised to a positive value in and of itself. The claim here is that legal judgment inevitably gets it right, and that rightness trumps all other values. Does the case before the judge involve someone who deliberately stole or defrauded and whose character could be charitably shaped by removing the stolen goods as a consequence of bad behaviour? Or might this be a case of inheritances or income that for technical reasons legally belongs to someone else, even though the claimant sincerely believed that it was theirs? In the latter case, it is hard to understand how removing it is an act of charity for that person, unless one subscribes to the absolute moral correctness of strict allocations of property according to legal logic. For the rabbis of this tosefta, behind the law lies its divine author, such that fidelity to the law may imply fidelity to God and God's will for humankind, regardless of the earthly effects of those legal judgments. Without a divine realm or "religious" sensibility, it is difficult to argue that removing wealth which the law has deemed another's is in any way a charitable act. We have seen this stance above, in the opinions of R. Eleazar b. R. Jose the Galilean and R. Eliezer b. Jacob on compromise - a stance which understands heavenly justice as protecting entitlements in an absolute sense. God is invoked by those rabbis to uphold the formal correctness of the law: God is insulted or His name blasphemed by evading strict legal judgments; and the law, like God himself, can shatter mountains. To make a person right in terms of divine law - even if it means impoverishing them - is to make them right before their Maker.

The final tosefta found at the end of the chapter does not settle the question of whether legal justice or compromise is preferable, but rather concludes each side of the argument independently. The adherents of legal justice once again invoke the divine sphere, while the proponents of compromise refer only to human, judicial procedure:

30 Shapira remarks about this view: "justice is ... determinative, and there is no room for tsedaqah in the sense of charity at all" (213). Nevertheless, tsedaqah is used to describe this act, and it does not make sense to believe that the rabbis completely uncharacteristically use an earlier understanding of the term, such as 'righteousness.' 
Judges should know whom they judge, before whom they judge, and who judges with them.${ }^{31}$ as it is said, "both parties to the dispute shall stand before the Lord" (Deut 19:17); and it says, "God stands in the divine assembly; among the divine beings $\mathrm{He}$ pronounces judgment" (Ps 82:1); and thus it says with regard to Jehoshaphat: "he said to the judges, "Consider [lit. "see"] what you are doing, for you judge not on behalf of human beings but on the Lord's behalf"” (2 Chron 19:6). And if the judge should say "why bother with all of this trouble?" is it not already stated: "and [he is] with you in giving judgment" [ibid.] - you only have what your eyes see.

R. Simeon b. Gamaliel says: just as legal judgment is with three, so mediated compromise is with three. The power of compromise is greater than the power of legal judgement, for if two render a legal verdict it may be reversed, but if two mediate a compromise it may not be reversed. (t. Sanh. 1:9; Zuckermandel p. 416)

The first half of this tosefta aims to blur thoroughly the lines between human and divine judgement by first elevating the human judge to the heavenly courtroom, and then conversely bringing the divine judge into the earthly courtroom. The tosefta follows from a previous pericope (cited below) which warned judges and witnesses not to be afraid of the actions or reactions of the litigants to undesired judgments, because legal judgment answers to a higher calling: divine arbitration of disputes and authority over legal judgments. Tosefta Sanhedrin 1:9 redirects that fear toward God and away from earthly concerns. It does so with a three-part exhortation paralleled by three verses from Scripture: a judge must know whom he judges - as Deut 19:17 spells out, parties to the dispute who stand before God himself as his people; before whom he judges - as Ps 82:1 tells us, "divine beings"; and with whom he judges - as 2 Chron 19:6 asserts, not men but God. The judge - and indeed the entire courtroom - is thus raised to the level of the heavenly assembly described in Ps 82, rendering any legal judgment a sacred task of the utmost sanctity and significance. To judge God's people before God and alongside God is not only a kind of imitatio dei, but a channeling of sacred presence to participate in a divine activity ("for judgment is God's").

Understandably, judges may then seek to withdraw from this highly sanctified and charged process - if they may cower before certain influential men, surely they would cower before the Almighty. But the tosefta responds that judges should already know how to quiet that anxious voice inside of them. Scripture has already said, in the continuation of the quotation from Chronicles above, that God is with you in giving judgment. Inverting the image above of the judge partaking in an activity that is rightfully God's and doing it with Him, here God assists in an activity that is quintessentially human and judges with you.

31 I have omitted a parallel section here that reiterates the same statement about witnesses, which appears (without the adjuration to judges) in the Mishnah. It seems out of place in this tosefta which brings verses entirely about judging, but even if it is original, it is not pertinent to the discussion here. 
It is here that the image of sight is invoked as the essentially human method for arriving at truth and legal judgment, which at first glance appears odd and jarring - up until now, in the tosefta, the judge has spent most of the time hearing and knowing rather than seeing. It emerges, I suggest, from the beginning of the verse, the word " $r e$ ' u," "consider," but literally translated as "look" or "see." It is as though Scripture is instructing judges not just to think, hear, and consider, but to see, and that it is in this act of seeing that God is said to assist the judges. I highlight this image because it is in fact consistent with biblical images of correct and impartial judgment, in which a bribe "blinds the eyes of the wise" (Deut 16:19), who therefore ought to see clearly when not on the take. It is also consistent with much of this toseftan chapter, which does not assume that a judge is or ought to be oblivious to features of the litigants that are readily apparent, such as their strength or weakness, their wealth or poverty. A judge must see these litigants in all their particularity, and he may even alter his actions on account of what he sees (perhaps by recusing himself, or taking personal action apart from his professional task as judge). Judges are expected to see and to note difference, rather than to blind themselves to these aspects of litigants or "universalize" each claim. Nevertheless, the adjustments they can make on account of these differences are limited, as they are still expected to adhere to strict standards of legal justice. But they are to know that they are supported in their observations and legal decisions by God, so that they are not too cowed by either the impulse to appease the influential or the anxiety over caring for the vulnerable.

And it is here that the tosefta turns again, and for the last time in this chapter, to the issue of compromise. While this pericope stands alone, stating a rule about the number of judges needed for legal judgment and compromise, the redactor places it out of its context, and it appears, to me, to be placed here as another answer, a "davar aher" to the judge's question: "why bother with all of this trouble"? "The power of compromise is greater than the power of legal judgment ..." - know, then, that compromise, mediation, is indeed an option that remains central in dispute resolution. By placing this pericope at the end of the chapter, the redactor takes sides in the argument among Tannaim over whether compromise is a commandment or a curse, seeing it as an ideal way to restore harmony and settle a dispute without having to sacrifice other essential values or live up to divine standards or judgment. Compromise emerges as more just than strict, legal decision making not only because it promotes a better and broader vision of justice but also because even when it is less than perfect (in this case, adjudicated by less than a full complement of judges), it is still effective.

\section{Summary}

In this section, we saw that as the tannaitic rabbis debate the question of whether legal justice or mediated compromise is a preferable form of dispute resolution, they essentially engage a question of political philosophy: what are 
the limits to the rule of law, and how can they be overcome? The rule of law's limits are identified as existing around the general values of "peace" (communal harmony) and "charity" (a spirit of generosity and material provision for the impoverished). The "rule of law" is understood to entail strict legal judgment: it may be a reliable mechanism for dispute resolution, but it may not result in a just society. Chapter one of Tosefta Sanhedrin provides three responses to this question: (1) Legal Justice is Justice - legal justice does not need to be supplemented, because ensuring that litigants conform to (divine) legal standards is generous and a social good; (2) Legal Justice and Generosity are Distinct - both virtues are necessary for a just society, but they are separate spheres which must run independently of each other; and (3) Legal Adjudication can be Generous and Just - mediated compromise is promoted as a dispute resolution mechanism which combines various ideals of social justice.

\section{Awareness of the Limits of Legal Justice: Hypotheticals in the Tosefta and Midrash}

In the previous section, we saw the ways in which the early rabbis explicitly distinguish legal justice (in most cases) from other social goods like peace or generosity. In this section, I endeavour to show another way in which the tannaitic rabbis display an awareness of the limits of legal justice: the construction of the hypothetical. The hypothetical, or hava amina, ${ }^{32}$ is the path not taken, the scenario raised by the rabbis that leads us down a false or unsustainable direction and must therefore be rejected. Rabbinic hypotheticals are used for a variety of purposes; one purpose they serve is to demonstrate that the rabbinic jurists did not act arbitrarily, that they considered all theoretical possibilities and had good reasons for making the legal choices they made. Thus, in constructing hypothetical alternatives to strict legal justice, the rabbis highlight several other modes of judicial decision making, all of which, according to Hanina Ben Menahem, use so-called "extra-legal" considerations as they "aim at arriving at a fairer and a more just solution to the dispute than would otherwise have been reached." ${ }^{33}$ These hypotheticals thus depict judges who see charity and generosity as integral to justice, or ones that factor emotions such as fear or shame into their judgments. The Tanaaim reject these approaches from the outset, but their raising of these possibilities and then excluding them constitutes a subtle acknowledgment of what legal justice can and cannot achieve.

As we saw above, one of the chief dilemmas the proponents of strict legal justice faced was the scenario in which a legal judgment went against a poor

32 A talmudic phrase indicating an initial assumption or theoretical possibility that is later rejected.

33 H. Ben-Menahem, Judicial Deviation in Talmudic Law: Governed by Men, Not by Rules, (New York: Harwood, 1991), 120. 
person and in favour of a wealthy one; such a scenario flew in the face of a rabbinic commitment to almsgiving and maintaining the poor. The rabbinic commentators therefore struggled with a difficult, and somewhat problematic, biblical commandment, which states that legal justice is supposed to be indifferent to a litigant's financial plight: "we-dal lo' tehedar beribo" (Exod 23:3). A literal translation of this phrase would read something like "you shall not honour the poor [man] in his lawsuit"; the root $h-d-r$ is used throughout the Hebrew Bible and contemporaneous literature in relation to the great and mighty, indeed even YHWH himself, ${ }^{34}$ and it is unusual to have it here used with the poor man as its object - so much so that the BHS critical edition of the Masoretic Text emends the word from we-dal (ודל; and a poor man) to gadol (גדל; a great man). ${ }^{35}$

What then does it mean to show honour or respect to the poor, then? It is a phrase that is counterintuitive precisely because the poor are most often degraded and treated with disdain. A midrash in the Mekhilta of R. Simeon b. Yohai on this same verse (Exod 23:3) attempts to answer this question with typical rabbinic logic which eschews any possibility of error in the biblical texts:

Neither shall you honour a poor man (Ex 23:3) Can it mean that one should not honour the poor with money? Scripture says: "in his cause" - that he shall not favour the poor in law; that you shall not say this man is poor, this man is of a good family, I will pronounce judgment in his favour and he will then be able to provide for himself honestly. For this it is said "neither shall you honour a poor man in his cause" and further on it is said "you shall not favour the person of the poor." (Lev 19:15) (Epstein-Melamed pp. 214-15)

The midrash identifies the chief way that the poor are expected to be 'honoured' in Jewish law - with money, by providing them with a livelihood. Because of this requirement, they cannot accept that the Torah would generally forbid people from honouring the poor; therefore, the midrash points out, the Torah is specific: although the poor must be honoured in general with the provision of material goods, in a legal case only one must put aside this obligation and not accord them this honour. Even though this line of reasoning is easy to follow, the midrash continues by providing a hypothetical scenario in which the poor is in fact honoured materially within the process of legal judgment: the judge could decide to rule in favour of the poor person if the other claimant were wealthy, thereby providing a "good, honest living" for him. This possibility, according to the midrash, is why the Torah must explicitly command that a poor person not be "honoured" in court.

What is interesting about this commentary is that nowhere does it make the claim that "honouring" the poor man by forcing the rich man to provide for

34 E.g., Is 2:10, 35:2; Ps 21:6, 145:5.

35 A parallel verse in Lev 19:15 makes this precise emendation: "you shall not lift of the face [fig. be partial to] the poor man, nor shall you honour (tehedar) the great [man]." 
him is a perversion or distortion of justice. ${ }^{36}$ Moreover, unlike in the Tosefta above, the word "charity" (tsedaqa) is never used for this judicial gesture that is offered to the poor man. In fact, the hypothetical case in the midrash actually has the judge thinking that a judgment in favour of the poor man - even if incorrect according to legal reasoning - provides him with an "honest" living: the word used here is "be-neqi'ut" which literally means cleanliness or purity, ${ }^{37}$ and is used throughout the Hebrew Bible to mean legal innocence. ${ }^{38}$ We might infer that there is a larger justice that is being served here in deciding in favour of the poor man, and forcing the rich man to provide for him. It is not a gesture of pity or mercy but rather a way of distributing wealth fairly while keeping the poor man's dignity intact. ${ }^{39}$ It is thus the principle of a more limited legal justice and the formal biblical requirement of the equal treatment of both litigants whether poor or rich, rather than anything inevitably necessary about legal processes, that prohibits the judge from taking into consideration the particular needs of the individual litigant and enacting a broader social justice in the courtroom.

Concerns about financial inequities are not the only ones which may tempt a judge away from adjudicating strictly according to the demands of statute and precedent; affect plays a role as well. The judge may himself feel things, or may intuit second-hand the emotional repercussions (and subsequent social fall-out) on the losing litigant, and may thus want to alter his legal rulings to achieve a better, and happier, result. In one midrash, the judge is afraid that the litigant against whom he rules will become violent and take revenge:

You shall not fear man. Lest you say: "I am afraid of so-and-so, lest he kill my children, or lest he set fire to my stacks of grain, or lest he uproot my planting." Scripture says: "do not be fearful of man, for judgment is God's." So also Jehoshaphat said, "He said to the judges, consider what you do, for you judge not for man, but for the Lord" (2 Chron 19:6) (Sifre Deut pisqa 17; Finkelstein p. 29)

In this case, the judge may very well have a legitimate fear of retribution, especially if we imagine courtrooms not as large, anonymous institutions but small tribunals whose decisions would ripple through small communities and villages. Rather than attempt to mitigate or respond to this fear, the midrash

36 The same is true for the parallel versions in the Sifra on Leviticus (Qedoshim 2.4) and Sifre Deuteronomy (p. 17), which all use the phrase "be-neqi'ut," and never cite biblical verses on the distortion or perversion of justice.

37 See Michael Sokoloff, A Dictionary of Jewish Palestinian Aramaic of the Byzantine Period ( $2^{\text {nd }}$ ed.; Ramat-Gan: Bar-Ilan University Press; Baltimore: Johns Hopkins University Press, 2002), 360 .

38 See, for example, Exod 23:7 and Ps 15:5.

39 This concept of preserving the dignity of the poor is elaborated by Gardner, Organized Charity, 139-56. That provision of the poor can be an aspect of justice, rather than charity, is shown in the rabbinic interpretation of the obligation to leave certain gleanings aside for the poor, understood as social justice rather than as charity: see G. E. Gardner, "Giving to the Poor in Early Rabbinic Judaism" (Ph. D. diss., Princeton University, 2009), 38-39. 
relegates such fear itself to the hypothetical, imagining that the judge can simply stop feeling afraid once he remembers his divine responsibility in the face of an all too human dread. It is possible that the midrash cites the verse from Chronicles to convey the added sense of the continuation of the verse (found in Tosefta Sanhedrin 1:9, discussed above). In this case, the judge might be exhorted to remember not only that he must aspire to divine standards in judging (and not give in to human fear), but also that "God is with [him] in giving judgment" - that God stands behind the judge as a kind of protective shield against petty retribution. Nevertheless, the midrash has once again, as above, created a hypothetical scenario with quite lasting rhetorical power the phrase "lest he kill my children" not easily shaken off. Rather than demonstrate that this fear can be mitigated, or argue that it is unwarranted, the midrash simply demands that it be quickly overcome, implicitly tolerating the further violence that can ensue as a result of strict legal justice.

Another approach to decision making based on fear of a violent aftermath is found again in Tosefta Sanhedrin chapter 1. Here the tosefta, in the context of the debate between legal justice and compromise, allows for one other possibility aside from ignoring the issue: recusal. The scenario the tosefta describes is somewhat unclear because of disputed textual transmission, but each possible reconstruction of the text offers an intriguing hypothetical:

R. Judah b Laqish says: two who come before one for judgment, one strong and the other weak - before one has heard their claims, or if one has heard their claims and doesn't know which way the case leans, one is permitted to say to them: "I will not be bound to you

MS1 (Vienna): lest the strong one is found liable and thus the strong one becomes his enemy."

MS2 (Erfurt): lest the strong one weak one is found liable and thus the strong one pursues him."

First Printed Edition: lest the strong one is found liable and thus the strong one becomes my enemy."

Once one has heard their claims and knows which way the case leans, one is not permitted to say to them: "I will not bind myself to you." And therefore it says: "do not be fearful of man, for judgment is God's." (Deut 1:17) (t. Sanh. 1:7; Zuckermandel p. 415)

In all the variants of this passage, the motivating factor in the judge recusing himself is fear of eliciting further violence, instability, or disharmony by definitively rendering a verdict in a dispute between a strong man and a weak man. ${ }^{40}$ Precisely what the scenario is that the judge fears is what is not preserved clearly in this text. In the first manuscript's scenario (as well as the one struck out by the second manuscript), the strong one is found liable, the weak litigant wins, and the strong one rather ominously is set at enmity with the weak one, thus increasing social disharmony as well as the likelihood of

40 In this hypothetical, the disparity between "strong" and "weak" most likely applies to physical stature and / or the ability of one litigant to menace the other. 
the strong one wreaking vengeance at some point in the future. Here, fear combines with the theme of charity or generosity toward the vulnerable by constructing a case in which the judge is not only fearful of a bad outcome, but shows compassion for the weak litigant and fears for his suffering. In this case, a judge is permitted to withdraw rather than inadvertently sic the strongman on the more vulnerable litigant.

The second manuscript's scenario differs slightly. In this case, the weak one is declared liable, but rather than making social relations easier, it sets up a situation in which the strong man, presumably in order to retrieve his owed settlement, "pursues" the weak man (we may imagine through mafia-like means). Once again, the judge here may recuse himself rather than foster further injustice by apparently taking the side of the strong man in his thuggish pursuit of debt repayment.

Finally, the printed edition's scenario is the one that hews most closely to the midrash in the Sifre discussed above. Here, the judge withdraws because he is afraid that in declaring the strong man liable, he either renders himself vulnerable to the strong man's vengeance, or, more broadly, that he increases social disharmony by further disenchanting the strong man from the judge and judicial processes, i.e., peaceful forms of dispute resolution. In such a scenario, the strong man would be likely to rely on private vengeance instead of the courts.

In any of these hypotheticals, recusal - the tosefta's remedy - is only a partial solution.

The verb $z-q-q$ used here to describe the relationship between the judge and the litigants is suggestive: a verb used to describe domestic cohabitation, and even in some conjugations the act of caring. ${ }^{41}$ The word choice is suggestive in the sense that the judge is not just performing a service or a public or sacred duty, but he is "binding" himself to the litigants - an act in which the judge appears to exceed his limited function as a nearly mechanical resolver of disputes. He comes to see their characters and lives, in all their particularities, and thus he also comes to see their futures. The only way out of an anticipated harmful or injurious future, for the "weak" litigant or for himself, here, is to disengage.

However, this option only obtains when the matter is unclear. If the judge has an inkling as to the proper judgment in the case, he must declare it. ${ }^{42}$ It appears that a judge may even inadvertently wind up binding himself to the litigants through his specialized knowledge of their situation; the tosefta again invokes the judge's sacred duty to impose legal justice despite his fears or concerns, this time citing Deuteronomy rather than Chronicles. The court system must continue to operate even in spite of a judge's reservations about

41 See Jastrow (1926), p. 410, for examples.

42 The same criterion is applied, in the previous tosefta, to a judge advising the litigants to seek mediation or compromise. 
the problems that might ensue as a result of it - but the justice or social good it results in, despite the divine imperative to make it happen, is debatable.

Fear is not the only emotion with social consequences that might interfere with a judge's rational, legal decision making - the rabbis also consider shame:

"Nor shall you honour a great man" (Lev 19:15). You shall not say, "he is rich and the son of great men - I will not put him to shame and see his shamefulness and the extent to which I shamed him." Therefore, it is said, "you shall not honour a great man." (Sifra Kedoshim 2:4)

The requirement not to defer to a rich or powerful man in a dispute is perhaps all too obvious. The midrashic commentaries, however, do not see it as a simple prohibition of cronyism or collusion with power. Instead, they presume that the judge has virtuous motives, thereby reinforcing the necessity of the explicit biblical prohibition. ${ }^{43}$ Generally, rabbinic law is sensitive to the gravity of publicly humiliating others; "shame" is included as one of the five primary damages in torts cases as outlined in Mishnah Baba Qama (8:1). According to the anonymous opinion of the mishnah there, a great man would be more susceptible to shame since the extent of the damage "follows one's honour" $(\mathrm{m}$. $B a b$. Qam. 8:6). The judge's deference to the great man, therefore, is not seen as simple bias but rather the desire to avoid further harm and injury as a result of the judicial process itself. Again, despite these altruistic intentions, the rabbis read the Torah as demanding adherence to legal justice, rather than attempting to seek a solution that respects both significant ideals.

A parallel text in Sifre Deuteronomy attempts just that - but rather than being framed as a compromise solution, it is positioned as a hypothetical:

Another interpretation: "You shall hear the small and the great alike" (Deut 1:17). Lest you say, "how can I damage the reputation of this rich man because of one denar? I will clear him of liability, and when he leaves the courtroom I will say to him: Give it to him since you are liable." Scripture says: "you shall hear the small and the great alike." (Sifre Deut 17; Finkelstein p. 28)

In the hypothetical of the Sifre, justice is done on two counts: the "small" man collects the small amount of money he is owed by law (one denar), and the rich man's dignity and honour remains intact. Everyone wins. The only value that has been sacrificed is equal treatment under the law, and the commitment to strict legal justice; nevertheless, these are the values of legal justice which the Torah will not sacrifice for the sake of perceived greater social goods. ${ }^{4}$

43 Rabbinic hermeneutics emphasize the omnisignificance of scripture; if a teaching is too obvious, the rabbis generally believe, it need not be stated explicitly in scripture. However, rabbinic midrash will often make this interpretive logic explicit, and they do not do that here. It is therefore not a necessary way of reading this text, and there may be other reasons why the rabbis fail to consider that the prohibition not to honour a great man does not refer simply to self-interested judicial bias in favour of the rich and powerful.

44 It is more difficult for us in the modern era to sympathize fully with the midrash's hypothetical here - in fact, strict legal justice in this case, precisely because it damages the 
Finally, the midrash discusses a scenario in which a litigants' shame might in fact be a desired outcome:

"You shall not pervert the judgment of the needy in his cause" (Ex 23:6) ... If you have before you a wicked man and an upright man, do not say that since this man is wicked, I will turn judgment against him. Therefore, it is said, "You shall not pervert the judgment of the needy in his cause" - one who is poor in good deeds. (Mekhilta Mishpatim Kaspa 20; Lauterbach pp. 472-73)

Here, as opposed to a situation in which the judge might desire to honour the litigant's dignity, the judge is faced with the opposite dilemma: the litigant before him is known to be wicked, and therefore the judge appeals to a greater sense of justice in which a generally good man should be honoured and rewarded, while a generally wicked man should be shamed and punished. ${ }^{45}$ Again, the judge is faced with a situation in which according to strict legal reasoning there may be one outcome, but according to a broader sense of justice and the values of society, there would be another. Once again, the midrash dismisses such broader considerations from the outset, presenting them as merely hypothetical; nevertheless, it has raised them and thus revealed the darker side of adherence to legal justice, in which legally "correct" decisions produce socially - and in this case morally - undesirable results.

reputation of the rich man, may seem preferable and more just. However, within rabbinic law there are many rules and legal exemptions provided to men of high status in order that they retain their dignity (again, see Gardner, Organized Charity, esp. 153-55 which demonstrates that not shaming those who fell from riches into poverty was so important that the community charity fund was enlisted to restore such people back to precisely the status they maintained before, even if that meant providing them with horses and slaves). Maintenance of the social order was seen as a real value for the rabbis, which makes this rejection of that value in the name of legal justice more radical than we might assume at first glance from a contemporary perspective, which often delights in humbling the rich and powerful.

45 In the parallel text in the Mekhilta of R. Simeon b. Yohai, the scenario is slightly different: "You shall not pervert the judgment of the needy" (Ex 23:6) Why do I need this? Has it not been stated already "you shall not pervert judgment" (Deut 16:19) either in favour of the poor or in favour of the rich? Why does it say "you shall not pervert judgment of the needy?" This is to include the case of a man who is poor in good deeds. For you should not say that since he is a wicked man he must be lying and this one must be telling the truth, and I will pervert the judgment against him. for this it is said "you shall not pervert judgment of the needy." (Mekhilta of R. Simeon b. Yohai, 23:6; Epstein-Melamed p. 215)

In this version, the dilemma that presents itself to the judge is not whether to proactively use his power in the situation to impose a justice greater than the case at hand by punishing the litigant's overall wickedness, but rather whether to use character assessment as a basis for rendering judgments about the veracity of the litigant's claims - a very different kind of predicament. According to this midrash, the Torah prohibits overall character assessment from being used as an element in judging a case, even though such judgments were common in contemporary Roman legal thought and practice. See A. Bryen, "Martyrdom, Rhetoric, and the Politics of Procedure," Classical Antiquity 33.2 (2014): 243-80, 249-50. 


\section{Summary}

In positing rejected hypotheticals, tannaitic literature does not depict gross miscarriages of justice or ways in which well-meaning judicial decisions can have subsequent deleterious effects on society. On the contrary, the rabbis time and again describe alternatives that appear to foster social harmony or mitigate systemic inequities, and we are shown judges who, to put it simply, care about people and society. The Tanaaim, however, dismiss this alternative in favour of circumscribed, rule-bound adjudication. I would therefore conclude that the Tanaaim of the midrash and the tosefta are well aware of the ways in which the universalized, one-size-fits-all legal justice they carve out for the courtroom falls short of justice as a broader ideal. This broader ideal is one that allows the poor to be supported with dignity, instead of with handouts; one that allows the rich and powerful to pay back what is owed without any personal humiliation accompanying it; and one that does not allow people of reprehensible character who toe the line of the letter of the law to get away unscathed. It is despite this vision of a greater kind of justice that the tannaitic rabbis prescribe and construct a narrower concept of legal justice.

In other words, we might see here a rabbinic attempt to draw a conceptual line between legal justice and other social institutions; to delimit and thereby construct a distinct sphere of legal rationality - an imperfect arena that simply cannot, and will not, result in social justice or communal harmony. ${ }^{46}$ The tannaitic rabbis thus drew the boundaries around an institution in which the "rule of law" could operate almost automatically, with no space allotted for the human face of judicial discretion, even in instances in which it might improve the morality or justice of the outcome.

\section{Opting for Strict Legal Justice: Putting the Rabbis in Context}

The question that inevitably lingers, then, is why - why would the Tannaim construct a system which could not by definition live up to their social ideals? Why define the law so narrowly so as to exclude the real pursuit of justice? To some extent, the answer is obvious: with the rabbis living under Roman imperial rule with its abundant propaganda promoting the ideology of the "rule of law,"47 as well as having inherited a Hellenistically-influenced tradition which itself was immersed in "rule of law" ideology, ${ }^{48}$ one would certainly be more surprised if the rabbis had abandoned this principle for one allowing a judge

46 The Tannaim that uphold judicial compromise as a valuable and perhaps even preferable method of dispute resolution would not agree with this conclusion; however, the majority of voices in tannaitic literature, as well as the fact that discussion and veneration of compromise is omitted from Mishnah, reveal that the dominant trend is toward narrow, rulebound decision making.

47 See Ando, Imperial Ideology, 49-50.

48 See LeFebvre, Collections, Codes, and Torah, 19 and Ando, Imperial Ideology, 47. 
freer use of his own wisdom, setting aside legal considerations to perform judicial magic along the lines of the biblical King Solomon.

Nevertheless, the rabbinic scrupulousness regarding judicial fidelity to strict, rule-bound decision making does not correlate easily with Roman "rule of law" platitudes or practice. Alongside fidelity to statutes and precedent, Roman judges were expected to both possess and deploy personal virtues in the process of making decisions, qualities such as fairness (aequitas), mercy (misericordia), and even humanity (humanitas). ${ }^{49}$ It is precisely qualities like these - or indeed wisdom (prudentia), which has a long and venerable biblical tradition - that the rabbis eject from legal decision making. I therefore would like to argue that the rabbis' negotiation with Rome here is not simple mimicry or simple resistance (or even a little bit of both), but rather an independent wrestling with the inherent difficulties posed by what is by then a hybrid Hellenistic-Roman-Jewish political concept of "rule of law," from the subject position of colonized provincials. In short, I suggest that the tannaitic rabbis dealt with the age-old dilemma in "rule of law" philosophy - that often rule-bound formalism does not produce justice and that often justice-guided discretion does not adhere enough to statute and precedent - by erring on the side of caution; and that they did so because from their subject position as the governed rather than the governors, the power of rule-bound systems was preferable to the power of unchecked individuals in positions of authority.

First, however, we must consider various other explanatory schemes that scholars have offered to make sense of tannaitic tendencies toward legal justice. Each explanation offers part of the story toward a more holistic picture of a dominant early rabbinic philosophy of the rule of law and judicial decision making, but none explains it fully.

Hanina Ben-Menahem argues that the rabbis generally, throughout posttannaitic rabbinic literature, strive for a justice that transcends mere adherence to rules. ${ }^{50}$ He therefore sees tannaitic literature as an anomaly, as "extremist" in its insistence on "strict enforcement of the law." ${ }^{11} \mathrm{He}$ concludes that the Tannaim thought this way because their work was a product of the study

49 See C.F. Noreña, Imperial Ideals in the Roman West: Representation, Circulation, Power (New York: Cambridge University Press, 2011), 64.

50 This view reflects the scholarly consensus. However, Deborah Barer's recent dissertation argues that again in the late redaction layer of the Babylonian Talmud, the stammaim presume a stance that requires rabbinic decision making to be rule-bound rather than discretionary. According to Barer, they do so because they do not wish to entrust fallible human adjudicators with the divine law. Why the amoraic rabbis, both in Palestine and Babylonia, seem much more comfortable with discretionary decisions that veer from statute and precedent is a question that remains open. See D. Barer, "A Judge with No Courtroom: Law, Ethics and the Rabbinic Idea of Lifnim Mi-Shurat Ha-Din" (Ph. D. diss., University of Virginia, 2016).

51 Ben-Menahem, Judicial Deviation, 122. Kirschenbaum simply explains this away by claiming it is not actually the case given later Jewish law (Kirschenbaum, Equity in Jewish Law, 111-12), but Ben Menahem shows - and this work confirms - that the tannaitic rabbis did indeed continually opt for strict legal formalism in judicial decision making. 
hall, rather than experience in real adjudication - hypothetical rather than practical. He writes:

The objection to the employment of extra-legal considerations embodied in the Midreshei Halakhah should be regarded as an expression of an ideal goal, the practical weight of which should not be overestimated. Ideal goals serve as directive principles. They guide but do not bind those to whom they are addressed, and they indicate certain tendencies without excluding dissenting opinions. ${ }^{52}$

While Ben-Menahem here correctly recognizes that tannaitic literature is both largely theoretical rather than a reflection of actual practice as well as interested in expressing ideals or even a kind of political philosophy, there is no reason to assume that the tannaitic rabbis in any way intended for their "opinions" to be read as non-binding, especially as many of them are directly linked to biblical commandments. Moreover, it is unclear to me what BenMenahem means to convey by stating that strict, rule-bound decision making is the "ideal goal" of the Tannaim, considering the myriad of ways in which the Tanaaim clearly do not position limited legal justice as an ideal, but rather as an uncompromising requirement of the Torah and / or the legal system they create. Therefore, while Ben-Menahem correctly identifies the mode of tannaitic literature (theoretical rather than practical), this in and of itself does not do enough to account for their somewhat peculiar adherence to rule-based adjudication.

While not commenting directly on judges or the hermeneutics of legal justice, Naftali Cohn, drawing on Beth Berkowitz (both of whom draw on Homi Bhaba), ${ }^{53}$ sees the tannaitic rabbis' juridical practice as mimicking Roman, legal culture. The rabbis do this as a kind of appropriation of power for themselves, and thus resistance to Roman power. By "fashion[ing] themselves as jurists ... of Judaean ritual law, the rabbis are imagining themselves in a Roman mold, but they are also asserting the primacy of their ancestral tradition.. ${ }^{54} \mathrm{In}$ the case of methods of adjudication, we might add to this that the rabbis imagine themselves as judging "in the Roman mold," but resist dominant modes of Roman judging by refusing the latitude Roman judges allocate to themselves, in a sense beating the Romans at their own game - outdoing them in their adherence to what is, after all, a Roman imperial ideal: the rule of law.

There is a lot to recommend this way of seeing early rabbinic adjudication, as both an internalization and repudiation of Rome; and in a sense, I certainly accept it as a partial explanation of this rabbinic phenomenon, even if it occurs at an unconscious level, as most ideological operations do. ${ }^{55}$ But I do not think

52 Ben-Menahem, Judicial Deviation, 123.

53 N.S. Cohn, The Memory of the Temple and the Making of the Rabbis (Philadelphia: University of Pennsylvania Press, 2012), 160 n. 93 and B. A. Berkowitz, Execution and Invention: Death Penalty Discourse in Early Rabbinic and Christian Cultures (New York: Oxford University Press, 2006), 161.

54 Cohn, Memory of the Temple, 17, 37.

55 Ando cites Bourdieu and Habermas to make this point (Imperial Ideology, 21-22). 
it is the whole story, particularly because as opposed to some of the texts that Cohn and Berkowitz discuss, there is no explicit or implicit engagement with Rome, or "the Kingdom," in these texts on judging. The rabbis here do not seem to be explicitly addressing the question of Roman dominance; instead, they seem to be entirely concerned with the very questions they raise: what is the best mode of judging? What kind of adjudication leads to social harmony and justice? And, finally, how are judges obligated to make decisions?

I would like to suggest that as the tannaitic rabbis address these "internal" questions of rabbinic legal theory, we should also be cognizant of the Roman, historical context from which they cannot be extricated. What is likely is that this context was not really Greek or Roman theoretical writing about political philosophy, but the provincial experience of Roman judging. According to ancient historians, Roman provincials were quite litigious. ${ }^{56}$ Legal activity was widespread in the Roman East, with many legal papyri having been discovered among the private estates of provincial families. ${ }^{57}$ It is fair to conclude, therefore, that the tannaitic rabbis had familiarity with Roman courts and Roman methods of judgment. As Amram Tropper puts it, "The presence of Roman legal jurisdiction and Greek-speaking lawyers in the Near East indicates that the fundamentals of Roman law were probably well known throughout the Graeco-Roman environment in Palestine." 58

According to Clifford Ando, the proliferation of legal documents in the Eastern Roman provinces is not simply a coincidence; provincials living in the Roman East turned to and relied on the law for a reason.

[W] e can ... see in surviving documentary texts the profound impression left by the government's claim to rationality: residents demonstrated their faith in the system when they played by its rules and especially when they attempted to exploit them. The survival of private copies of official documents, as of personal archives, testifies to a deep-seated trend. ... Individuals kept such documents because they had faith in the rationality of Roman administration. They believed that it would abide by its established rules, whether they liked those rules or not. ... The private collections of documents bore fruit in the remarkable array of surviving petitions that cite such precedents in formulating their own case. ${ }^{59}$

In other words, Ando argues not only as we saw above that the Roman imperial government created the impression that the "rule of law" was important to them (their "claim to rationality"), but that the provincials for the most part accepted this imperial claim and attempted to hold them to their own standards by collecting precedent and presenting rational, legal arguments before Roman officials. To the extent that we can tell, this is true of Jewish provincials as well. A statement in Mishnah Avot, usually understood as referring to Ro-

\footnotetext{
56 Ando, Imperial Ideology, 375.

57 Ando, Imperial Ideology, 380.

58 A. Tropper, Wisdom, Politics, and Historiography: Tractate Avot in the Context of the Graeco-Roman Near East (New York: Oxford University Press, 2005), 191.

59 Ando, Imperial Ideology, 376, 380
} 
man principles of law and order, ${ }^{60}$ may reflect this accommodationist stance among Jews: "R. Hannah deputy of the priests said: Pray for the welfare of the kingdom since, but for the fear of it, each one of us would have swallowed his neighbour alive" ( $m$. Avot 3:2, trans. Tropper p. 260). And, according to Ando, Jewish provincials did not just fear the Roman government, but also engaged with it: "the Greek texts in the dossier of Babatha reveal a woman eager to exploit Roman law and Roman authorities in order to settle a host of longstanding legal disputes ..."61

Therefore, Roman law was not only known to provincials, but it was embraced by them, not only to gain advantage and settle disputes with neighbours, but as a kind of general mode of empowerment. Again, Ando writes: "Provincials absorbed and iterated those ideas that they wished their overlords to endorse, embody, and express. Above all, provincials exploited ideological tropes that gave them leverage over civiles principes." 62 Pushing this argument further, Ari Bryen takes seriously how defenceless non-Roman provincials would have been before Roman governors and views legal practice as perhaps the only relatively effective mode of empowerment for provincials. He reminds us that:

[t] he governor was the total authority in the provinces in dealings with individuals who were not Roman citizens. ... Provincials worried about the possibility that the governor would shed his trappings of civility and indulge what they imagined to be his innate tendency toward improvised street violence. ${ }^{63}$

There was nothing that provincials could do to change those asymmetrical dynamics. However, they might find respite from it in the law:

The courtroom was a sacred space, in the sense that it was the site of a particular set of ritualized interactions. ... [T] he governor in the courtroom would be obligated to sit passively, to listen to claims, and to interrogate (that is, to ask and be answered). As such, the courtroom was a space in which the power dynamics of the everyday were temporarily suspended, negotiated, and potentially reconfigured.

... As such, the law contained a particular form of power: the power to force imperial authorities to bring themselves or others into conformity with provincial desires, and the power to force officials to change their behavior or to enforce a change in the behavior of another party. However, these moments of power could only be produced in the courtroom, and only accessed in it. ${ }^{64}$

Indeed, Bryen, following Ando, sees the provincial population's ability to access written statute and precedent as the very means by which ordinary sub-

60 See, e. g., B. S. Jackson, “Jewish Approaches to Law (Religious and Secular)," Law \& Justice The Christian Law Review 164 (2010): 63-74, 63 n. 1.

61 Ando, Imperial Ideology, 381.

62 Ando, Imperial Ideology, 47, emphasis mine.

63 A.Z. Bryen, "Judging Empire: Courts And Culture in Rome's Eastern Provinces," in Law and History Review 30, no. 3 (August 2012): 771-811, 781-82.

64 Bryen, "Judging," 799-800, 807. 
jects could get admittedly limited leverage over a Roman governor. It was precisely the Roman commitment to "play by the rules" that bound their hands in the courtroom and allowed provincials a modicum of power in relation to them:

The eastern provincials relied on a concept of law which was something substantially new in Roman legal thinking concerning the governing of subjugated peoples. This vision of the law was founded on the idea that there existed a disembodied world of rules that transcended even the emperor himself, and that these rules could be accessed by the skillful manipulation of authoritative legal texts in the context of courtroom encounters structured by proper procedure. ${ }^{65}$

It was only by tapping into this textual universe that subjugated provincials could seize a moment in which they could, before the Roman government, "articulate their views of the ways the world should be working."66

Therefore, I submit that the idea that a judge in a courtroom would be bound by statute and precedent, writings which are in some manner public and predate the event of adjudication, would have been an attractive, if not necessary ideal for (especially non-citizen) provincials living under Roman rule. It was a significant safeguard against arbitrary power, and perhaps the only predictable means of obligating a provincial governor to respond to an imperative greater than the powers of his local office. Law could be seen as a tool which would give provincials a voice in Roman affairs, and often give them the upper hand.

In imagining the role of rabbinic judges in their own writings, the Tanaaim are not particularly concerned about reining in excesses of judicial power. In fact, likely imagining themselves or their colleagues serving as judges (which they seem to have done from time to time), ${ }^{67}$ it is clear from the texts above that the early rabbis only thought the best of potential judges, positing that they would be motivated by ideals of justice, generosity and caring. In spite of this, these same rabbis were also most likely accustomed to thinking of the courtroom as a "ritualized space" in which the power of legal statute and precedent, of a "disembodied world of rules," could topple the mightiest of governors by neutralizing his authority to act arbitrarily. The power of such an imaginary about the force of law could easily overwhelm a more pragmatic assessment of judicial discretion in instances that could lead to greater justice or social harmony. The Tanaaim that did champion the value of compromise, or pesharah, were perhaps able to recognize the limits of such a formal system of "disembodied" legal justice: that while it may allow for a temporary subjugation of an individual's official authority under the binding power of legal imperatives, it does not produce outcomes that create a better society or com-

65 Bryen, "Judging," 776, emphasis mine.

66 Bryen, "Judging," 802.

67 See H. Lapin, Rabbis as Romans: The Rabbinic Movement in Palestine, 100-400 CE (New York: Oxford University Press, 2012), chapter 4: "Provincial Arbitration." 
munity. Nevertheless, the prevailing view in tannaitic texts in favour of rulebound adjudication is consistent with the enthusiastic pursuit of rule-bound justice among eastern provincials in Roman courts.

\section{Conclusion}

I have shown that tannaitic literature implies an awareness that strict legal justice does not necessarily lead to greater social good. Despite this, on the whole, the tannaitic rabbis refrain from giving the judge discretion to take into consideration the specific needs of individual litigant or other, more general, social needs or ideals; the judge, as stated again and again in tannaitic literature, is required to follow the rationality of legal statute and adjudicate accordingly. I have accounted for this somewhat strange quirk of tannaitic legal thought by arguing that the rabbis did not only subscribe to the general ideals of "rule of law" that the Romans, and Greeks before them, promoted in the provinces, but that their position as disempowered, largely non-citizen provincials would have encouraged them to read that ideology as formally as possible, because doing so allowed the courtroom to become a place where well-informed litigants could wield both real and discursive power over the Roman government. Such an understanding of what the "rule of law" means in practice, in the courtroom, could certainly have held sway when the rabbis imagined their own ideal courtrooms, and the procedures that judges would have to adhere to.

Such a reading of tannaitic legal thought requires us to suspend preconceived notions that legal systems of dispute resolution are inherently or inevitably formal, rule-bound, and universal. It also leads us toward the acknowledgment that the justice of the courtroom is not just amorphously synonymous with "justice" writ large: mishpat is distinct from tsedaqa and shalom and no one term or concept covers all of these social values for the rabbis. We find the Tanaaim not simply responding to the demands of legal justice, but constructing and re-inscribing, at various different points, a definition of "law" in opposition to another value. Each time they do so, they imbue legal discourse with power over other modes of dispute resolution, community building, or meaning making - for good or for ill. 